\title{
Teaching as an act of stewardship: Theology in practice
}

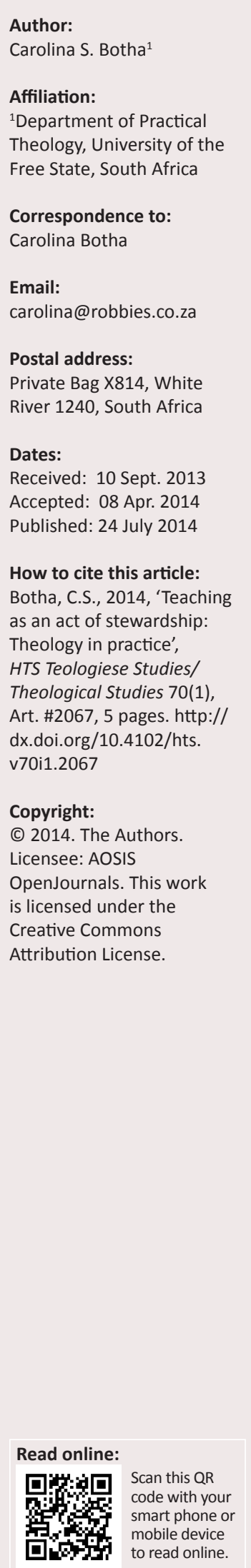

The concept of stewardship has evolved from merely being significant in the financial contribution that people make towards their church to an all-encompassing decision that dictates people's lives. It is not a feeling of urgency that someone is born with, but rather a decision and commitment made on a daily basis. Teachers thus find themselves in the perfect situation to be stewards in their classrooms on a daily basis. Furthermore, this tendency is noticed in teachers who work towards turning their schools into stewardship-driven institutions that aim to develop an environment driven by a calling to teach; therefore, theology is offered a leading role in the way the school is managed.

\section{Introduction}

The commitment towards being a steward of God is not a feeling or an urgency that most people grow up with; it consists more of a functional decision that needs to be made on a daily basis. It is not a task or a commission that one has to work towards, but instead it is a personal commitment and choice that is validated and renewed on an ongoing basis. This article is the result of a series of conversations with teachers that postulates the possibility of biblical stewardship and servant leadership as being a suitable platform from which South African teachers can consider their own placement within the social construction of teaching and practical theology in South Africa.

\section{Journey through the Bible}

The Christian principle of stewardship is based on the belief that:

$[H]$ uman beings are created by the same God who has created the entire universe and everything in it. To look after the Earth, and thus God's dominion, is the responsibility of the Christian steward. (Sidoti 2013:n.p.)

A Biblical view of stewardship is conventionally defined as 'utilizing and managing all resources God provides for the glory of God and the betterment of His creation' (Bugg 1991:1303).

There are 26 direct references to 'steward' or 'stewardship' in the Old and New Testament. Hall (1991:10) clarifies that the Old Testament mostly refers to the Hebrew word ashurbet, whilst the New Testament uses the term oikonomia. The direct translation of both these words relates to the management of the household of a ruler or a king.

The steward of the Old Testament was depicted as a servant, but not merely as a slave. Such a person was a foreman or supervisor of sorts, responsible for making appropriate decisions, giving orders and generally managing the household. Holding such a position implied a certain relationship of trust and shared responsibility between the steward and the owner of the household. Throughout the history of Christianity, the concept of stewardship had migrated to the relationship between patrons and the church. Sharing in the responsibility of carrying the financial burden of the church fell upon the patrons. Stewardship also included spreading the gospel and making the church a bastion of love and hope for Christians and searching souls.

'This, then, is how you ought to regard us: As servants of Christ and as those entrusted with the mysteries God has revealed'. Here, in 1 Corinthians 4:1, Paul further applies this principle of stewardship to himself and to the church. Tooley (1966:75-76) explains that 'we have here the most pregnant use of the metaphor in the New Testament and one which throws light on Paul's understanding of leadership in the church'. Although the focus on stewardship has been connected to the financial contributions that Christians made towards the growth of the kingdom of God, Tooley (1966:75-76) urges Christians to remember that true leadership, and per implication stewardship, includes taking care of each other and to share the responsibility for each other in more areas than just finances. Herein we find the modern message of stewardship. 


\section{Faces of stewardship}

Throughout the last few decades, stewardship has thus found its way from the traditional view of it being concerned only with management of money and finances, to the heart of people's religion. This created opportunities for Christians to not only be stewards in the church, but also in their everyday lives. Teachers, even more than many other professions, have the privilege of being stewards not only during Sunday's church service when they give their offers, but also in all the relationships they form with colleagues, parents and children. They have to, through the merging of their professional lives and their spirituality, be a living example of God's love to the world.

In that way, their role as a teacher offers them the unique opportunity to approach stewardship in more ways than just the obvious. It is therefore important that teachers explore and become accountable for their own conceptualisations of the different faces that stewardship can take on. A group of teachers involved in conversations about stewardship explored the following components of stewardships and the ways in which they practice it in their classrooms:

- Steward of material possessions: A large part of the traditional definition of stewardship focuses on the believer giving back a substantial part of his or her income as a way of showing gratitude towards God. Followers of Christ choose to support their churches and missionary work in times when the whole world is under financial pressure. Teachers are not exempt from being influenced by financial issues and concerns, and therefore money and material possessions often have an impact on decisions teachers have to make about their lives. Most teachers have to work hard to find a consensus between the realities and expenses of living and their desire to be stewards of God in every sense of the word.

- Steward of the environment: Schools share in the responsibility of teaching children how to 'improve the quality of the environment, to decrease pollution, and help the earth to be more capable of sustaining natural ecosystems' (The American Scientific Affiliation n.d.). Promoting recycling and fostering a love for the environment from a young age enables a teacher to act as a steward of the environment.

- Steward of time: Edgar (2003:130) writes that in their role as stewards, Christians have the responsibility to spend their time as wisely as they can. Being a steward of time can be a significant challenge for the teacher dedicated to his or her work and his or her own family. Very often teachers would sacrifice their personal time and time to keep up to date with duties such as class preparation and marking; feeling guilty when they are not working creates tension within themselves and their families. The challenge is to find the balance between all different areas of life and to strive towards being accountable to yourself, your colleagues, family and foremost to God for the way in which you spend your time.

- Steward of gifts: According to Burger (2005:160), people receive different gifts and talents from God that add to the richness of their lives. Christians have the responsibility to embrace the diversity of these gifts and to use them to become effective stewards for the kingdom of Christ. God has bestowed many different gifts on people and having the ability to teach can thus be seen as a spiritual gift. Extracurricular activities can also be considered an extension of the talents and gifts that teachers can use to enrich the lives of the children they work with. A teacher therefore stands in duty of God to prepare children to become active parts of the body of Christ (Rm 12:6; 1 Cor 12:7; $1 \mathrm{Pt} 4: 10)$.

- Steward of life: In essence, stewardship of life boils down to consciously making enlightened decisions in terms of how to use opportunities that crosses a person's path (The American Scientific Affiliation n.d.). All teachers can testify to this where they have used opportunities to influence children's situations or decisions. Being a steward of life motivates teachers to be sensitive to such situations and to use every chance to its fullest potential. This further includes being there for learners who face challenges in their lives outside of the school environment. Very often, school becomes the only space wherein these children feel safe and thus the social responsibility that teachers have directly links to their choice to be stewards of God.

- Steward of knowledge: Proficient teachers will constantly evaluate their own levels of expertise and will search for ways to use their unique physical, mental and emotional abilities to improve their knowledge. Not only are teachers responsible for building a base of external knowledge in children, but they should also inspire them towards a process of lifelong learning and should inspire children to create a love for learning. Motivating themselves to keep up with developments in their own fields of specialisation very often feels like an insurmountable task given their existing workload, but the reality is that stewardship of knowledge should also include their own knowledge and not only that of the learners sitting in front of them.

- Steward of the gospel: In 2 Corinthians 5:19-20, Paul explains that God wanted the message of reconciliation to be shared by the entire world; this message has been entrusted to the church (Hall 1991:101). The church has the obligation to share the love, mercy and Gospel of Jesus Christ with the rest of the world. Schools, and per implication teachers, have the same responsibility. Spreading the gospel in such a way has always been a cornerstone of the Christian faith and a primary task that God has imparted on his children. The responsibility that schools have in advancing the Gospel of Jesus Christ has increased exponentially since the perception that schools are seen as the primary educators of children has become generally accepted. The reality that schools have become multireligious domains has forced teachers to not only proclaim their love of God through the words they speak, but also through their actions.

- Steward of relationships: Both stewardship and education are corporate acts. To have an attitude of stewardship requires a genuine involvement with and concern for that which is entrusted to a person's care. Christian stewards 'speak the truth in love and hold one another to the very highest standards' (Dick 2009:n.p.). Sharing the responsibility of being stewards in classrooms, on school grounds, in the staff room and in interaction with parents, 
creates a mutual platform for teachers where they can reflect and dream together. In the same sense, it creates the potential for the release of resources and energy that can enhance the effort of the individual teacher to endorse the love and grace of God in the classroom. It is important to note that teachers also have an impact outside the borders of the classroom or even the gates of their school. This eventually flows into the cumulative and larger society in which they live and teach.

\section{Stewards in the light of the cross}

In the New Testament, Jesus Christ displays a new societal model of stewardship through his devotion and righteousness. Jesus never considered himself the focal point of his work. He was obedient to his master and responsible for his master's interests on earth. Traditional theology paints Jesus Christ as king, priest and prophet, but practical theology awards us the freedom to consider also the example that Jesus set as a steward.

It would be a modernistic outlook to consider Jesus Christ as a mere example of what a steward should be. A post-foundationalist approach to practical theology would look beyond the example and realise that it is the prior stewardship of Jesus into which, through the Spirit and through faith we are initiated' (Hall 1991:44).

As a result, we have to remember that everything is a bountiful gift from God including our bodies, minds, souls and relationships. Jesus reiterates the importance of handling these gifts in a responsible way through the parables he shares in the New Testament.

This puts stewardship in a category that expects more from a person than just accepting responsibility for certain areas; instead it creates a purpose. God bestows these talents upon us not as an act of generosity, but as an act of trust. Christians therefore become responsible for the 'whole family of humanity' (Hall 1991:37). Stewardship can be seen as:

$[A]$ worldview that encompasses all of life ... including what we feel (e.g. arts, aesthetics, relationships, worship), what we think (e.g. philosophy, theology, history, science), and what we do (e.g. technology, work, finances, social action, spiritual disciplines). (Miller \& Miller 1997:212)

\section{A vehicle of God's grace in the classroom}

If teachers view themselves as stewards of God, it implies that they ought to relinquish the right to believe that all authority at the school revolves around them. If they see themselves as stewards for the kingdom of Christ, then God is in control of everything that happens at their school including academic aspects as well as every emotional and social interaction teachers have with their learners. In terms of leadership, Sergiovanni (1992) writes that:

[T] he leadership that counts in the end, is the kind that touches people differently. It taps their emotions, appeals to their values and responds to their connection with other people. It is morallybased leadership - a form of stewardship. (p. 270)

The interaction between praxis and theory in the practical theological domain urges people to question the dominant discourses even further. Applying the biblical principles of stewardship in practice in a classroom means that, as teachers, individuals are expected to use the talents and gifts that God has given them in a responsible way.

This same principle applies to many of their colleagues who see themselves as living out the many faces of stewardship on the battlegrounds that schools can sometimes become. Teachers who see themselves as stewards will have a different kind of relationship with the children in their class than teachers who simply see themselves as a conveyer of academic knowledge.

Many children and adults will be able to share detailed accounts and anecdotes about teachers who influenced their lives. During those times, their school became more than just a place of learning; it had been turned into a community where people touched the hearts of other people and where people became the embodiment of the example set by Jesus Christ.

\section{Stewardship is about transformation and not about organisational survival}

If you ask many teachers what they do, the answer of most will not be 'I teach'; they will rather say 'I am a teacher'. The difference in response is semantic, yet subtle and powerfully important. The social construction of these words carries exceptional meaning. 'To teach' means it is simply a job that you do, a professional qualification that you have, and a skill that you possess. Using the phrase 'I teach' suggests an action that is initiated and then completed. It calls for a direct object, namely the conveyance of academic knowledge. 'To teach' can therefore easily become impersonal, the children easily forgotten, and the focus solely on the curriculum.

On the other hand, the statement 'I am a teacher' implies something inherent and continuing (Botha 2012), something that is not only a job description, but also engrossing and encompassing. To be a teacher is to embrace a certain identity, to let your whole being voluntarily be labelled with the connotation and discourses attached to being an educator. Rather than just setting test papers or preparing lessons, the caring teacher tries to look through their learners' eyes. These individuals struggle with them in search of their own destinies and their own way of making sense of the world. This mind-set is considered as connected teaching wherein care is practiced not from an expert filling a hierarchal position, but from a position of being alongside a child.

Schools in South Africa are caught up in the grip of politics and forced changes. Children and their needs are often left behind in order to meet administrative demands. Teachers who see themselves as stewards work hard at still doing what they believe schools are there to do. For them it is about investing in children's future and about guiding them to discover the gifts and talents that God has bestowed upon them. 
They struggle to do so in classes filled with learners from other religions or learners who do not practice any religion at all. Such teachers find their inspiration in the situations they have to deal with. Through their endeavours they discover that investing their time, money, energy and gifts are closely related to their ultimate goal on earth, namely to honour God through everything that they do. They stand not only in service of the South African Department of Education - they stand in service of their God. Their stewardship is a reality that they live every day.

Their love for God and for children motivates them to overlook the frustrations and to focus on the opportunities that this occupation affords them to spread the gospel of the Lord. Not only do such teachers act as leaders in their communities, they are also leaders in their schools due to their commitment to stewardship, thereby becoming part of the decision-making process and part of the structure that defines the character of the school.

\section{Envisioning a school that is true to its calling to stewardship}

When teachers make the mind shift to not only see themselves as stewards for the kingdom of God, but to rather see themselves functioning as part of an organic structure that works towards living out stewardship, their whole conceptualisation will change of what a school community is supposed to look like. I agree with Hunt (1991:152) when she warns that a sense of community cannot be forced. It does not emerge just because people are in the same room or in the same profession. It emerges slowly as a network of trust grows between people who live by the same values and who nurtures one another - it is indeed slow and cumbersome work. The same principles apply to the development of a school that is driven by a calling to spread the Gospel of Jesus Christ. It is a lengthy and extensive process wherein teachers with the same passion and dream work towards slowly transforming their school into a community of care. When teachers who consider themselves to be stewards for Christ start talking about this conviction and start living in the way that they deal with their daily work and the children they teach, a dynamic process is started in a school in which theology becomes immersed in the daily running of the school.

Ackermann (2003:27) speaks of ideal communication between Christians as being characterised by four prerequisites:

- Firstly, it is 'non-authoritarian' and therefore takes place 'between free subjects on an equal basis'.

- Secondly, the 'unconditional freedom of the participants is presupposed'.

- Thirdly, the 'unconditional acceptance of others as individuals entitled to authentic existence is posited'.

- Finally, 'Christian communication is conducted in the context of love'.

If we are able to put into practice this kind of open, loving communication, the 'Christian hope for the actualization of the "reign of God", when love, justice, freedom, peace and wholeness will flourish' (Ackermann 1998:89), might become a reality in our lives. These premises are not only a description of the characteristics and principles of Christian communication, but are also very similar to the goals of a school that is driven by this calling. Evaluating the ethos of a school against these criteria can give the teachers of that school an indication of how far they have come on their quest to becoming a school driven by a calling and thereby living out their purpose of being stewards for the kingdom. The following aspects can be considered as some of the core characteristics of such an establishment:

- Diligence: Teachers working hard in terms of their curricular and extra-curricular duties do it to honour their God. This also includes staying up to date with the newest developments in their chosen academic field. Teachers have the responsibility to give their learners the best academic education they possibly can.

- Being grateful: Christian teachers believe that they have been saved by the grace of God and they are humble and thankful for the success they achieve.

- Loyalty: Teachers at a school dedicated to God are loyal to their colleagues and will display a sense of loyalty to the school when they find themselves in situations where the school is under discussion (Botha 2012:240).

- Act in truth: Because teachers in a school true to its calling will consider themselves as stewards to the kingdom of Christ, their perception of the truth will be different from the secular perception thereof. Values like honesty, sincerity and integrity are crucial components of a school built upon their Christian convictions (Botha 2012:241). These teachers will live by example.

- Unselfish service: Due to teachers' calling to stewardship, such a school will focus on the needs of others. Teachers will search for opportunities to uplift the community and support schools that might not be as effective and productive as they are.

- Focused on reconciliation: Diversity is a reality in South African schools - even more so in schools that had to adapt to a multicultural milieu. The unfortunate reality is that not all children grow up in homes where diversity is acknowledged and reconciliation is promoted (Botha 2012:241). The onus for educating children in this area of life thus falls upon the school. An attitude of tolerance, forgiveness and the creation of equal opportunities establish a living space where the soul of the child is more important than the history of a country or the colour of a person's skin.

- Accepts responsibility: As a steward, teachers need to accept responsibility for their learners, colleagues and their schools' facilities (Botha 2012:242). The African concept of Ubuntu promotes the sharing of the responsibility for the children entrusted to the care of a school. However, the principle of stewardship also urges teachers to reach further than just the learners sitting behind desks in their classrooms. It also includes the desks itself as well as the rest of the facilities at that particular school. This often leads teachers to the realisation that the facilities do not belong to the teachers or to the school - it belongs to God. Therefore, teachers who pride themselves on their stewardship have to take care of such facilities as they would take care of their own bodies that they consider to be temples of God. 
- Be a community of hope: Teachers are not only responsible for caring for each other, but are very often considered the primary educators and creators of the only safe space these children have access to. Often children are given the message at home that there is no hope or future for them or for their country. However, the Gospel of Jesus Christ offers us hope for eternal salvation (Botha 2012:242). Through the blood of Jesus and the input of the Holy Spirit, Christians are awarded a new life. This offers the assurance that God will let everything work out for the best for those who keep to his will. In a world built upon pessimism, war, conflict and destruction, a school focused on its calling will be a beacon of hope. As a direct result, teachers will become guardians and agents of hope for themselves, their colleagues, their pupils and the greater community.

De Pree (1992:13) emphasises the need for teachers to contribute to society when he states that the art of leadership requires us to think about the leader-as-steward in terms of relationships: Of assets and legacy, of momentum and effectiveness, of civility and values'. Sergiovanni (1992:139) asserts that stewardship 'involves the leader's personal responsibility to manage her or his life and affairs with proper regard for the rights of other people and for the common welfare'. In that way, the bigger picture of education in South Africa can be influenced by Christian teachers living out their commitment towards stewardship through servant leadership. Schools that live out this stewardship and consider themselves as schools with a calling to teach will create more safe environments where theology, rather than politics, will dictate the manner in which the school is managed.

\section{The symbioses of stewardship and practical theology}

Stewardship has many different dimensions that touch on and encompass all aspects of human behaviour. Practical theology is also intimately concerned with the human being's journey with life and with God. The social constructions and discourses that people use to order their professional and personal lives are therefore also connected to their spirituality. Being a steward or a servant leader can therefore not only be confined to certain convenient areas of an individual's life, but should be visible in all areas. Ganzevoort (2004:53) anticipated this when he said that 'practical theologians will need to develop both explicit or Christian and implicit or secular language'.

In the world of practical theology the ultimate example of stewardship set by Jesus Christ provides the guidelines around which individuals, in this case teachers, can shape their models of practice. Moving around in the realms of stewardship has the potential to bring about transformation and a lived-through spirituality in teachers that will filter through to colleagues and to the learners in their schools, thus creating schools living out a calling to teach.

Greenleaf (2002:151) refers to how such teachers (and by implication schools) are viewed by others when he states that 'effective servant leaders can be so subtle about it that all anybody is likely to see is the result. They don't see the cause'. When teachers are obedient to the voice of God, they become a part of the final song. They then realise that living involves being called and that true stewardship means to be responsible for one's choices, and that servant leadership can sometimes be the antidote against the challenges and frustrations they face. It is in responding to these commissions from God that teachers open themselves up to not only be children of God, but to be active contributors to the kingdom of Christ.

\section{Conclusion}

Living as a steward of God whilst being a teacher in South Africa is a multifaceted endeavour; such teachers quickly conclude that they are not accountable to the Department of Education, but rather to their God. Therefore, they will set out to be more than just conveyers of academic knowledge; they will strive towards being mentors and examples to the children they teach. They will view their schools as more than a place of employment and will see it as an opportunity to live out their calling to teach - it will become a breeding ground for the act of stewardship.

\section{Acknowledgments Competing interests}

The author declares that she has no financial or personal relationship(s) that may have inappropriately influenced her in writing this article.

\section{References}

Ackermann, D.M., 1998, 'A voice was heard in Ramah: A feminist theology of praxis for healing in South Africa', in D. Ackerman \& R. Bons-Storm (eds.), Liberating faith practices: Feminist practical theologies in context, pp. 75-102, Peeters, Leuven.

Ackermann, D.M., 2003, After the locusts: Letters from a landscape of faith, William B. Eerdmans Publishing Company, Grand Rapids.

Botha, C.S., 2012, 'High school teachers as agents of hope: A practical theological engagement', PhD thesis, Department of Theology, University of Free State.

Bugg, C., 1991, s.v. 'Stewardship', in Holman Bible dictionary, p. 1303, Holman, Nashville.

Burger, C., 2005, Ontmoetings met die lewende God: Hoe God ons roep, nuut maak - en stuur, Lux Verbi, Wellington.

De Pree, M., 1992, Leadership jazz, Dell Publishing Group, New York.

Dick, D.R., 2009, The care and feeding of faithful stewards, viewed 17 March 2011, from http://doroteos2.com/2009/06/24/the-care-and-feeding-of-faithful-stewards/

Edgar, B., 2003, 'Time for God: Christian stewardship and the gift of time', Evangelical Review of Theology 27(2), 128-137.

Ganzevoort, R.R., 2004, 'Social construction and normativity in practical theology 1' in C.A.M. Hermans \& M.E. Moore (eds.), Hermeneutics and empirical research in practical theology: The contribution of empirical theology by Johannes A. Van der practical theology: The contribu
Ven, pp. 53-74, Brill, Leiden.

Greenleaf, R., 2002, Servant-leadership, viewed 17 March 2011, from http://www. greenleaf.org/whatissl/

Hall, D.J., 1991, The Steward: A biblical symbol come of age, William B. Eerdmans, Publishing Company, Grand Rapids.

Hunt, M.E., 1991, Fierce tenderness: A feminist theology of friendship, Crossroad, New York.

Miller, K.B. \& Miller, R.T., 1997, 'Taking the road less travelled: Reflections on entering careers in science', Perspectives on Science and Christian Faith 49(4), 212-214.

Sergiovanni, T.J., 1992, 'Leadership as stewardship: Who's serving who?', in T.J. Servgiovanni (ed.), Moral leadership, n.p., Jossey-Bass Publishers, San Francisco.

Sidoti, C.W., 2013, 'Advent is time to reflect on how to imitate Christ', in Vision, viewed 17 March 2011, from http://www.nacc.org/vision/2013-Nov-Dec/Advent-is-timeto-reflect-on-how-to-imitate-Christ-by-Charles-W-Sidoti-pr.asp

The American Scientific Affiliation n.d., Christian Stewardship, viewed 17 March 2011, from http://www.asa3.org/ASA/education/views/stewardship.htm

Tooley, W., 1966, 'Stewards of God: An examination of the terms oikonomon and oikonomia in the New Testament', Scottish Journal of Theology 19, 74-86. http:// dx.doi.org/10.1017/\$0036930600002040 